\title{
The Impact of Work-Family Conflict and Emotional Intelligence on Nurse's Performance at Dr. Pirngadi Hospital
}

\author{
Romauli E. G. Siallagan ${ }^{1}$, Arlina Nurbaity Lubis ${ }^{2}$, Sri Eka Wahyuni ${ }^{3}$ \\ ${ }^{1}$ Correspondence Author: romauli.e.g.s@gmail.com \\ ${ }^{1}$ Master of Nursing Program, Faculty of Nursing, Universitas Sumatera Utara, Medan, Indonesia \\ 2Master of Nursing Program, Faculty of Nursing, Universitas Sumatera Utara, Medan, Indonesia \\ ${ }_{3}$ Master of Nursing Program, Faculty of Nursing, Universitas Sumatera Utara, Medan, Indonesia

\begin{tabular}{ll}
\hline I N D E X I N G & A B S T R AC T \\
\hline Keywords: & $\begin{array}{l}\text { A hospital is one of the healthcare facilities for society. The success of a hospital is } \\
\text { indicated by the quality service of the Nurse. A good performance of the nurse is } \\
\text { intelligence; }\end{array}$ \\
expected to give the best treatment for the patients. A profession as a nurse is not \\
Work-family \\
easy for a married woman with children because she has a double function, as a \\
housewife and a nurse. Both functions may impact on the performance of nursing. \\
The study was to identify the impact of work-family conflict (WFC) and emotional \\
intelligence (EI) on the performance of nurses at Dr. Pirngadi Hospital Medan. \\
Quantitative correlation descriptive with a cross-sectional design was applied in this \\
study. The population of the research is 115 nurses. Data were analyzed by using the \\
Spearmen correlation coefficient test. The results show that both WFC and EI impact \\
on the performance of nurses at Dr. Pirngadi Hospital Medan. Mostly nurses (69.6 \%) \\
were highly impacted by WFC and $67.8 \%$ of them were in the low level of emotional \\
Intelligence.
\end{tabular}

Kata kunci:

Kecerdasan

emosional;

Kinerja;

Konflik keluarga

pekerja;

\begin{abstract}
Rumah sakit merupakan salah satu sarana kesehatan bagi masyarakat. Keberhasilan suatu rumah sakit ditunjukkan dengan kualitas pelayanan Perawat. Kinerja perawat yang baik diharapkan dapat memberikan perawatan yang terbaik bagi pasien. Profesi sebagai perawat tidaklah mudah bagi wanita yang sudah menikah dan memiliki anak karena memiliki fungsi ganda yaitu sebagai ibu rumah tangga dan perawat. Kedua fungsi tersebut dapat berdampak pada kinerja keperawatan. Penelitian ini bertujuan untuk mengetahui pengaruh work family conflict dan kecerdasan emosional terhadap kinerja perawat di RSUD Dr. Pirngadi Medan. Deskriptif korelasi kuantitatif dengan desain cross sectional digunakan dalam penelitian ini. Populasi penelitian adalah 115 perawat. Data dianalisis dengan menggunakan uji koefisien korelasi Spearmen. Hasil penelitian menunjukkan bahwa WFC dan IE berpengaruh terhadap kinerja perawat di RSUD Dr. Pirngadi Medan. Sebagian besar perawat (69,6\%) sangat terpengaruh oleh BPTA dan 67,8\% diantaranya memiliki Kecerdasan Emosional rendah.
\end{abstract}

C) 2020 JMMR. All rights reserved

Article history: Received 2020-11-03; Revised 2020-12-26; Accepted 2020-12-29

\section{INTRODUCTION}

Nursing is an important profession for healthcare that may fulfill the patient's needs (Haryanti, Aini, \& Purwaningsih, 2013). Female nurses are the majority in the hospital (Desi Wulandari, 2014). Nurses are a dominant profession compared to the others in the healthcare case. A nurse as a healthcare worker has formal education and a responsibility to give treatment to the patients. The nurse only has a high relationship with the patient's family (Haryanti et al., 2013). The nursing profession considered a social worker should have competence and calm in giving treatment to the patients. It describes that human resources are polite and hospitable (Susanti, 2013).

However, psychologically the nurses feel guilty during doing their nursing because they feel neglected by their family. Many nurses could not overcome their problem even though high competence. If the female nurse could not harmonize the double function, she indeed 
will get a problem. It potentially evokes a conflict between a housewife and a nurse (Desi Wulandari, 2014).

According to the study on 110 male nurses and 137 female nurses indicates that female nurses more susceptible to work-family conflict compared to male nurses. Work-family conflict (WFC) is caused by a positive relationship between a housewife and a nurse. The higher the needs of both functions, the more potential of conflict (Susanti, 2013). This study is by the research on 138 married female nurses with children that $50.4 \%$ chronically impacted and $41.4 \%$ impacted in the past 6 months (Takeuchi \& Yamazaki, 2010). Another study in Madura indicates from 30 nurses, $42 \%$ are impacted by WFC (Khoiroh, 2015). While a study in Italia on 500 nurses indicates that there is a correlation between the double function (Ghislieri, Gatti, Molino, \& Cortese, 2017).

Nurses are majority impacted by WFC because of heavy-duty and responsibility for the safety of the patient. Various characters of nurses are created by various work sections, such as shift schedule, tight discipline, rivalry among nurses (Widyasari, 2010). WFC harms the performance. However, support from teamwork may minimalize the conflict and maximize the performance (Wang \& Tsai, 2014). The nurses who impacted WFC may cause feel tired, the bad mood on work, etc. (Wibowo, 2017).

Emotional intelligence (EI) has a positive impact on performance (Uha, 2013). EI is very important to stimulate, oppose frustration, empathize (Rantika \& Sunjoyo, 2011). Emotional control must avoid conflict. Those who have a good EI can fulfill the needs of the patient including sociology, biology (Anand et al., 2016). Both individual and company by performance achievement are based on EI, while the performance is based on IQ (MacCann et al., 2019).

Nurses should have morality, intellectuality, technical ability, and interpersonal communication (Wibowo, 2017). The nurse's performance is indicated by the nursing process and documentation. Hence, a standard achievement will impact the quality of nursing (Barker \& Nussbaum, 2011). To give quality service, the nurse should have communication ability, investigate health conditions with an interview, check physic, diagnosis defining, and collaboration with teamwork (Simamora, Bukit, Purba, \& Siahaan, 2017).

\section{RESEARCH METHOD}

The study was conducted using correlation descriptive study with a cross-sectional approach. The study was conducted at Dr. Pirngadi Hospital Medan. The subject was 115 selected by total sampling. Inclusion criteria, namely: the nurse is female; married has children; minimum education level is Diploma III in nursing; length of work $>2$ years; nurses who have children under 21 years of age; and BOR for inpatients $>40 \%$. Exclusion criteria, namely: study permit; and nurse who is on OJT (on the job training).

The WFC questionnaire is a modified instrument from (Carlson, Kacmar, \& Williams, 2000) study which has been well validated (higher than 0.361) to measure WFC based on the established model. The questionnaire has 18 positive statements consisting of a scale of 6 dimensions, time-based work interference with family, time-based family interference with work, strain-based work interference with family, strain-based family interference with work, behavior-based work interference with family, and behavior-based family interference with 
work. The study applied the Likert scale model consisting of 5 options such as: strongly agree $=5$, agree -4 , less agree $=3$, disagree $=2$, and strongly disagree $=1$.

THE modified EI questionnaire from (Daniel Goleman, 2015) is also a well-validated scale (higher than 0.361) to measure WFC based on the established model. The questionnaire has 30 positive statements with a scale of 6 dimensions, consisting of selfawareness, self-regulation, self-motivation, empathy, and social skills. The study applied Likert scale with 5 options, such as: choice on a positive statement strongly agree $=5$, agree $=4$, disagree $=3$, disagree $=2$, and strongly disagree $=1$.

The modified performance questionnaire from (Mangkunegara, 2007) was also wellvalidated (higher than 0.419) to measure WFC based on the established model. The questionnaire has 22 positive statements with a scale of 5 dimensions consisting of assessment, nursing diagnosis, nursing planning, nursing implementation, and nursing evaluation. The study applied the Likert scale with 4 options in positive statements, namely: do/yes value of 1 and not done/no value of 0 . Chi-square was applied to examine the relationship between EI and the nurse's performance at RSUD Dr. Pirnga in Medan city. Multivariate analysis with multiple logistic regression was used to measure the highest influence on nurse's performance.

\section{RESULT AND DISCUSSION}

Characteristics of nurses at Dr. Pirngadi Hospital Medan as follows: majority nurses (39.1\%) aged 31 to 40 years old and minimum nurses $(0.9 \%)$ aged $>50$ years old. Mostly (63.5\%) nurses are based on Diploma (D3) as educational background. Based on the length of working, mostly nurses (46.9\%) work 1 to 5 years, and others $(19.1 \%)$ work 6 to 10 years. Mostly nurses (69.6 \%) at Dr. Pirngadi Hospital Medan are highly impacted category by WFC and $67.8 \%$ of nurses are in the low level of Emotional Intelligence, while $68.7 \%$ of nurses are in bad performances.

Table.1 Characteristic of nurses at Dr. Pirngadi Hospital Medan ( $\mathrm{n}=115)$

\begin{tabular}{|c|c|c|c|}
\hline No & Variable & Frequency & $\%$ \\
\hline \multicolumn{4}{|l|}{ Age } \\
\hline 1 & $<21$ years & 3 & 2.6 \\
\hline 2 & $21-30$ years & 39 & 33.9 \\
\hline 3 & $31-40$ years & 45 & 39.1 \\
\hline 4 & $41-50$ years & 27 & 23.5 \\
\hline \multirow[t]{2}{*}{5} & $>50$ years & 1 & 0.9 \\
\hline & Total & 115 & 100 \\
\hline \multicolumn{4}{|c|}{ Education } \\
\hline 1 & Diploma III & 73 & 63.5 \\
\hline \multirow[t]{2}{*}{2} & Ners & 42 & 36.5 \\
\hline & Total & 115 & 100 \\
\hline \multicolumn{4}{|c|}{ Length of working } \\
\hline 1 & $1-5$ years & 54 & 46.9 \\
\hline 2 & $6-10$ years & 22 & 19.1 \\
\hline \multirow[t]{2}{*}{3} & $>10$ years & 39 & 33.9 \\
\hline & Total & 115 & 100 \\
\hline \multicolumn{4}{|c|}{ Work-family conflict (WFC) } \\
\hline 1 & Low & 80 & $6 ., 6$ \\
\hline 2 & High & 35 & 30.4 \\
\hline
\end{tabular}


Table.1 (continued) Characteristic of nurses at Dr. Pirngadi Hospital Medan ( $n=115)$

\begin{tabular}{cccc}
\hline No & Variable & Frequency & $\%$ \\
\hline \multicolumn{2}{c}{ Emotional Intelligence (EI) } & 115 & 100 \\
1 & High & 37 & 32.2 \\
2 & Low & 78 & 67.8 \\
\multicolumn{2}{c}{ Total } & 115 & 100 \\
\multicolumn{2}{c}{ Performance } & & \\
1 & Good & 36 & 31.3 \\
2 & Bad & 79 & 68.7 \\
\multicolumn{2}{c}{ Total } & 115 & 100 \\
\hline
\end{tabular}

Bivariate analysis is to determine the relationship between work-family conflict together with emotional intelligence and performance of nurses at Dr. Pirngadi Hospital Medan by using a chi-square test with $\mathrm{p}$-value $=0,05$. Table 3 shows of 80 nurses impacted by WFC at a high level, there are $25.5 \%$ in good performances and $55.0 \%$ are in bad performances. Of 35 nurses impacted by WFC at a low level, there are $11.0 \%$ in good performances and 24.0 $\%$ in bad performances. Based on the chi-square test, so: $p=0,000<\alpha=0,05$, Ho has rejected means there is a relationship between work-family conflict and performance of the nurses at Dr. Pirngadi Hospital Medan. Of 37 nurses with a high level of emotional intelligence, there are $11.6 \%$ in good performances and $25.4 \%$ are bad performances. Of 78 nurses with a low level of emotional intelligence, there are $24.4 \%$ in good performances and $53.6 \%$ in bad performances. Based on chi-square test, so: $p=0,000<\alpha=0,05$. Ho is rejected means there is a relationship between emotional intelligence and performances of the nurses at Dr. Pirngadi Hospital Medan.

Table. 2 Relationship between work-family conflict and nurse's performance

\begin{tabular}{|c|c|c|c|c|c|c|c|c|c|}
\hline \multirow{3}{*}{ No } & \multirow{3}{*}{ Work-Family Conflict (WFC) } & \multicolumn{4}{|c|}{ Performance } & \multirow{2}{*}{\multicolumn{2}{|c|}{ Total }} & \multirow{3}{*}{$\chi^{2}$} & \multirow{3}{*}{ p-value } \\
\hline & & \multicolumn{2}{|c|}{ Good } & \multicolumn{2}{|c|}{ Poor } & & & & \\
\hline & & $\mathrm{f}$ & $\%$ & $\mathrm{f}$ & $\%$ & $\mathrm{~F}$ & $\%$ & & \\
\hline 1 & High & 4 & 25.5 & 76 & 55 & 80 & 100 & 84,575 & 0.000 \\
\hline \multirow[t]{2}{*}{2} & Low & 32 & 11 & 3 & 24 & 35 & 100 & & \\
\hline & Emotional Intelligence (EI) & & & & & & & & \\
\hline 1 & High & 28 & 11.6 & 9 & 25.4 & 37 & 100 & 49,943 & 0.000 \\
\hline 2 & Low & 8 & 24.4 & 70 & 53.6 & 78 & 100 & & \\
\hline
\end{tabular}

Table. 3 shows that independent variables of work-family conflict with p-value 0.000 (p $<0.05)$ and emotional intelligence with p-value $0.000(\mathrm{p}<0.05)$ have an impact on the dependent variable of performance of nurses at Dr. Pirngadi Hospital Medan. Multiple logistic regression was applied to examine the relationship with a significant level $<0.05$. It indicated that emotional intelligence has a dominant influence $34.480(95 \% \mathrm{CI}=3.797$. 313.103. 
Table. 3 Impact of work-family conflict and emotional intelligence on the performance of nurses at Dr. Pirngadi Hospital Medan.

\begin{tabular}{lccccc}
\hline Independent Variable & B-value & p-value & Exp (B) & \multicolumn{2}{c}{$95 \%$ C. I for Exp(B) } \\
\hline & & & & Lower & Upper \\
1. Work-family conflict (WFC) & -5.502 & 0.000 & 0.004 & 0.000 & 0.038 \\
2. Emotional intelligence (EI) & 3.540 & 0.002 & 34.480 & 3.797 & 313.103 \\
Constant & 2.944 & 0.46 & 18.984 & & \\
\hline
\end{tabular}

Among the highly impacted WFC category, there are $55 \%$ in poor performances. While in those who low category, there are $11 \%$ good performances. Based on multiple logistic regression tests that there is a significant relationship between work-family conflict and performance of nurses at Dr. Pirngadi Hospital Medan with value $p=0,000<\alpha=0,05$. Nurses in the high category of WFC, their performances will decrease, conversely those who have the low category of WFC, the performances will be better. The nurses who have a high category of WFC is caused by the double functions, as a housewife and a nurse. A housewife also has a responsibility to take care of the children and sometimes has to skip the schedule at work. As a profession, a nurse has to obey the schedule at work and other regulations and sometimes has no time for the family. On the side, even though the nurses have a high category of WFC, but they can do the best nursing for the patients because they think that the quality service is very important.

$11.6 \%$ of nurses having high emotional intelligence are good performances, and 53.6 $\%$ of low-level emotional intelligence are poor performances. Based on multiple logistic regression tests, there is a significant relationship between emotional intelligence and the performance of nurses at Dr. Pirngadi Hospital Medan with a value $p=0,000<\alpha=0,05$. It can be inferred that the nurses having a high emotional intelligence will serve better, conversely, for those having low emotional intelligence will be worse service. The nurses who can control their emotions well will ease to develop their initiative. Those have a good relationship with others will also impact on performance. Based on results, there are three nurses with high emotional intelligence, but they have poor performances. According (Darmadi, 2014) that many factors impact individual performance including remuneration, support, ability, perception on the job, and work satisfaction. Referring to the study of (Mulyono, 2013) that work satisfaction impacts on the performance of nurses. It indicates that besides emotional intelligence, other factors also influence the performance of nurses.

\section{CONCLUSION}

This study concludes that work-family conflict and emotional intelligence significantly impact on the performance of nurses at Dr. Pirngadi Hospital Medan with OR $=-5,502$, and coefficient of 3.540 on the emotional intelligence variable. It means the factor which impacts on the performance of nurses at Dr. Pirngadi Hospital Medan is dominated by emotional intelligence. Nurses should distinguish between a housewife and a nurse. To do the best on duty, the nurses need support from the family and colleagues. Setting working hours must be flexible to accommodate the double function of a female nurse. The management of the hospital should hold training in ESQ to improve the caring service of the nurse. Other activities are crucial to intensify the performance because a study at Dr. Pirngadi Hosptal in 2008 indicated $59.6 \%$ of nurses in moderate stress, $9.9 \%$ in high-level stress, and $4.6 \%$ in 
very high-level stress. It can be concluded that the nurses at Dr. Pirngadi Hosptal are at moderate stress levels.

\section{REFERENCE}

Anand, R., Perrelli, R., Zhang, B., Papi, L., Koeva Brooks, P., Allard, C., ... Medina, L. (2016). WP/16/24 South Africa's Exports Performance: Any Role for Structural Factors? IMF Working Paper African Department and Strategy, Policy, and Review Department South Africa's Exports Performance: Any Role for Structural Factors*.

Anwar Prabu Mangkunegara. (2007). Manajemen Sumber Daya Manusia Perusahaan. Bandung: PT REMAJA ROSDAKARYA BANDUNG.

Barker, L. M., \& Nussbaum, M. A. (2011). Fatigue, performance and the work environment: A survey of registered nurses. Journal of Advanced Nursing, 67(6), 1370-1382. https://doi.org/10.1111/j.1365-2648.2010.05597.x

Carlson, D. S., Kacmar, K. M., \& Williams, L. J. (2000). Construction and Initial Validation of a Multidimensional Measure of Work-Family Conflict. Journal of Vocational Behavior, 56(2), 249-276. https://doi.org/10.1006/jvbe.1999.1713

Daniel Goleman. (2015). Emotional Intelligence. Jakarta: Gramedia Pustaka Utama.

Desi Wulandari, R. D. (2014). Relationship Between the Role Conflict With Multiple. Psycho Idea, 33-41.

Ghislieri, C., Gatti, P., Molino, M., \& Cortese, C. G. (2017). Work-family conflict and enrichment in nurses: between job demands, perceived organisational support and work-family backlash. Journal of Nursing Management, 25(1), 65-75. https://doi.org/10.1111/jonm.12442

Hamid Darmadi. (2014). Metode penelitian pendidikan dan sosial: (teori konsep dasar dan implementasi). Bandung: Alfabeta.

Haryanti, H., Aini, F., \& Purwaningsih, P. (2013). Hubungan Antara Beban Kerja Dengan Stres Kerja Perawat Di Instalasi Gawat Darurat Rsud Kabupaten Semarang. Jurnal Manajemen Keperawatan, 1(1), 111590.

Khoiroh, M. (2015). Hubungan Konflik Peran Ganda Kerja-Keluarga dengan Kesejahteraan Psikologis Perawat Perempuan di Puskesmas Guluk-Guluk Sumenep Madura. Universitas Islam Negeri Maulana Malik Ibrahim Malang.

MacCann, C., Jiang, Y., Brown, L. E. R., Double, K. S., Bucich, M., \& Minbashian, A. (2019). Emotional Intelligence Predicts Academic Performance: A Meta-Analysis. Psychological Bulletin, 146(2), 150-186. https://doi.org/10.1037/bul0000219

Mulyono. (2013). Pengaruh Kinerja Perawat di Rumah Sakit TIngkat III Ambon. Junal AKK, 2(1), 18-26.

Rantika, R., \& Sunjoyo. (2011). Pengaruh Konflik Kerja-Keluarga Terhadap Komitmen Oragnisasi yang Dimediasi oleh Kepuasan Kerja Pada Profesi Perawat di Rumah Sakit 
Umum Daerah (RSUD) DR. Moewardi Surakarta. Jurnal Manajemen Teori Dan Terapan, 4(2), 28-43. Retrieved from https://ejournal.unair.ac.id/JMTT/article/viewFile/2418/1773

Simamora, R. H., Bukit, E., Purba, J. M., \& Siahaan, J. (2017). Penguatan Kinerja Perawat Dalam Pemberian Asuhan Keperawatan Melalui Pelatihan Ronde Keperawatan Di Rumah Sakit Royal Prima Medan. Jurnal Pengabdian Kepada Masyarakat, 23(2), 300. https://doi.org/10.24114/jpkm.v23i2.6880

Susanti, S. (2013). Peran Pekerjaan, Peran Keluarga Dan Konflik Pekerjaan Pada Perawat Wanita. Persona:Jurnal Psikologi Indonesia, 2(2), 183-190. https://doi.org/10.30996/persona.v2i2.118

Takeuchi, T., \& Yamazaki, Y. (2010). Relationship between work-family conflict and a sense of coherence among Japanese registered nurses. Japan Journal of Nursing Science, 7(2), 158-168. https://doi.org/10.1111/j.1742-7924.2010.00154.x

Uha, I. N. (2013). Budaya Organisasi Kepemimpinan dan Kinerja. Jakarta: Kencana.

Wang, M. L., \& Tsai, L. J. (2014). Work-family conflict and job performance in nurses: The moderating effects of social support. Journal of Nursing Research, 22(3), 200-207. https://doi.org/10.1097/jnr.0000000000000040

Wibowo. (2017). Manajemen kinerja (V). Jakarta: Rajawali Pers.

Widyasari, Y. (2010). Persepsi Mahasiswa Akuntansi Mengenai Faktor-Faktor Yang Membedakan Pemilihan Karir (Studi pada Universitas Diponegoro dan UNIKA Soegijapranata. 